\title{
E-Marketing dan Keunggulan Kompetitif terhadap Kinerja Pemasaran dengan Online Review sebagai Variabel Moderating
}

\author{
E-Marketing and Competitive Advantage to Marketing \\ Performance with Online Review as Moderating Variables
}

\author{
Siti Alhamra Salqaura1 ${ }^{*}$, Rizky Christian Sipayung ${ }^{2}$, Siti Sabrina Salqaura3 \\ 1)Prodi Manajemen, Fakultas Ekonomi dan Bisnis, Universitas Medan Area, Indonesia \\ 2)Prodi Manajemen, Politeknik IT\&B Medan, Indonesia \\ 3)Prodi Agribisnis, Fakultas Pertanian, Universitas Medan Area, Indonesia
}

*Coresponding Email: Siti.alhamra01@gmail.com

\begin{abstract}
Abstrak
Tujuan penelitian ini adalah untuk mengetahui dampak e-marketing dan keunggulan kompetitif terhadap kinerja pemasaran dengan online review sebagai variabel moderating pada perusahaan e-commerce di Indonesia. Penelitian ini merupakan penelitian deskriptif kuantitatif dan sifat penelitian merupakan deskriptif explanatory. Metode pengumpulan data dilakukan melalui kuesioner yang disebarkan secara online kepada 50 orang di seluruh Indonesia. Adapun teknik pengambilan sampel dengan metode purposive sampling. Metode analisis data yang digunakan adalah menggunakan structural equation model (SEM) dengan menggunakan software SMART-PLS 3.0. Hasil penelitian menunjukkan terdapat pengaruh yang positif dan signifikan antara $e$ marketing dan kinerja pemasaran. Keunggulan kompetitif memiliki pengaruh positif namun tidak signifikan dengan kinerja pemasaran. Sementara online review tidak mampu memoderasi hubungan antara e-marketing dan keunggulan kompetitif terhadap kinerja pemasaran. Berdasarkan hasil penelitian diperoleh koefisien determinasi (R2) 0,644 mengindikasikan bahwa variabel kinerja pemasaran dipengaruhi oleh variabel $e$ marketing, keunggulan kompetitif dan online review sebesar 0,644 atau $64,4 \%$ sementara sisanya dipengaruhi oleh variabel-variabel lain di luar penelitian ini.
\end{abstract}

Kata Kunci: E-Marketing, Keunggulan Kompetitif, Kinerja Pemasaran, Online Review.

\begin{abstract}
The purpose of this study was to determine the impact of e-marketing and competitive advantage on marketing performance with online review as a moderating variable in e-commerce companies in Indonesia. This research is a quantitative descriptive research and the character of the research is explanatory descriptive. The data collection method was carried out through questionnaires distributed online to 50 people throughout Indonesia. The sampling technique is purposive sampling method. The data analysis method used is a structural equation model (SEM) using SMART-PLS 3.0 software. The results showed that there was a positive and significant influence between e-marketing and marketing performance. Competitive advantage has a positive value but not significant effect on marketing performance. While online reviews are not able to moderate the relationship between emarketing and competitive advantage on marketing performance. The results showed that the coefficient of determination (R2) is 0.644 as the marketing performance variable is influenced by the e-marketing, competitive advantage and online review variables of 0.644 or $64.4 \%$ while the rest is influenced by other variables outside of this study.
\end{abstract}

Keywords: Competitive Advantage, E-Marketing, Marketing Performance, Online Review. 


\section{PENDAHULUAN}

Proses digitalisasi dalam dunia bisnis membuat para pengusaha harus berkecimpung dalam dunia e-commerce (Magdalena \& Ellyani, 2018). Electronic commerce (e-commerce) atau perdagangan elektronik secara umum dapat didefinisikan sebagai segala bentuk aktivitas jual beli yang dilakukan melalui media elektronik (Mariana, 2012; Nayoan, 2021). Bentuk-bentuk dari $e$ commerce dapat berupa media saluran televisi, telepon, internet, email, dan segala jenis perdagangan tanpa tatap muka untuk meningkatkan efisiensi waktu dan biaya yang akan berdampak pada peningkatan hasil penjualan. Menurut Data Statistik E-Commerce 2019 (Badan Pusat Statistik, 2019) jumlah usaha yang memanfaatkan internet terlihat pada Tabel 1.

Tabel 1 Jumlah Persentase Usaha yang Memanfaatkan Internet

\begin{tabular}{cc}
\hline Tahun & Jumlah (\%) \\
\hline$<2010$ & $1,53 \%$ \\
\hline $2010-2016$ & $28,06 \%$ \\
\hline $2017-2018$ & $45,30 \%$ \\
\hline 2019 & $25,11 \%$ \\
\hline
\end{tabular}

Sumber : E-Commerce 2019 (Badan Pusat Statistik, 2019)

Berdasarkan hasil pendataan, sebanyak $45,30 \%$ usaha e-commerce di Indonesia mulai memanfaatkan internet pada rentang tahun 2017 sampai dengan tahun 2018, usaha yang mulai memanfaatkan internet di tahun 2010 -2016 sebanyak 28,06\%, sedangkan yang baru mulai menggunakan internet pada tahun 2019 sebanyak $25,11 \%$ dan yang mulai memanfaatkan internet sebelum tahun 2010 hanya sebanyak 1,53 persen. Lebih lanjut berdasarkan data statistik (Badan Pusat Statistik, 2019), selama tahun 2018 transaksi dari 13.485 usaha $e$ - commerce sebanyak 24.821.916 transaksi dengan nilai transaksi yang mencapai 17,21 triliun rupiah. Dari data tersebut bisa dikatakan bahwa rata - rata setiap usaha e-commerce melakukan transaksi selama tahun 2018 sebanyak 1.841 kali dengan rata-rata nilai transaksinya sebanyak 694 ribu rupiah.

Pada e-marketing, terdapat berbagai jenis dimensi salah satunya adalah dimensi sales marketing dengan membagikan e-coupon kepada pengguna aplikasinya. Hal ini merupakan program yang dipopulerkan untuk bersaing antar $e$ commerce. E-coupon dapat berupa potongan harga produk, diskon ongkos kirim, hingga program flash sale yang kerap diadakan oleh para $e$ commerce seperti flash 11.11 dan flash 12.12 yang diadakan Shopee setiap bulan. Fenomena yang terjadi sejak munculnya $e$-commerce adalah konsumen mulai meninggalkan praktik belanja offline, karena perbedaan harga suatu barang di setiap daerah menyebabkan konsumen lebih tertarik untuk membeli online di e-commerce dengan harga yang lebih murah dan potongan harga serta gratis ongkos kirim.

Selain itu, kesulitan masyarakat di seluruh bagian Indonesia untuk mendapatkan persediaan barang-barang tertentu yang baru dan belum tersedia di pasar konvensional / offline juga kerap menjadi pemicu pembelian secara online melalui e-commerce. Sebagai contoh ketika awal pandemic Covid-19 persediaan hand sanitizer, masker dan face shield yang kosong di berbagai apotik dan swalayan dihampir semua kota di Indonesia kebutuhan tersebut melalui internet. Online review juga turut berpengaruh ketika masyarakat hendak membeli sesuatu dari toko 
online di e-commerce. Ketika hendak melakukan pembelian, konsumen kerap kali membaca review / ulasan yang ditinggalkan oleh pembeli sebelumnya pada aplikasi e-commerce tersebut. Online review yang baik akan meningkatkan kinerja pemasaran e-commerce tertentu. Bad reviews / ulasan buruk juga kerap menjadi masalah pada perusahaan e-commerce di Indonesia.

Zhao et al., (2015) mengungkapkan bahwa online reviews terbentuk dari 6 dimensi yaitu: (1) usefullness of online review; (2) reviewer expertise; (3) timeliness of online reviews; (4) volume of online reviews; (5) valence of online review (positive \& negative); dan (6) comprehensiveness of online review.

Kinerja pemasaran dipengaruhi oleh e-marketing. Hasil penelitian Iddris \& Ibrahim (2015) pada UMKM di Ghana menunjukkan bahwa UKM yang menggunakan e-marketing menunjukkan dampak positif terhadap kinerja pemasaran UKM. Selain itu, $e$-marketing juga berpengaruh terhadap e-loyalty konsumen (Irmal et al., 2020). Tjiptono \& Chandra (2020) membagi fungsi-fungsi utama $e$ marketing mencakup 11 elemen yang dirumuskan menjadi 4P+P2C2S3 yaitu:1) Product, meliputi product assortment, configuration engine, dan alat perencanaan serta lay out; 2) Price, terdiri atas dynamic pricing, forward auctions, reverse auctions, dan name-your-price; 3) Place, seperti afiliasi dan remote hosting; 4) Promotion, mencakup online ads, sponsored links, outbond email, viral marketing, dan rekomendasi; 5) Per-sonalization, meliputi customization, individualization, rulesbased system, dan collaborative filtering; 6) Privacy, terutama menyangkut data-data pribadi pelanggan; 7) Customer service, misalnya frequently asked questions (FAQ), help desk, email response management, dan chat; 8) Community, contohnya chat rooms, user ratings \& reviews, registries \& wish lists, dan reputation scoring; 9) Site, yaitu homepage, navigation \& search, dan disain serta layout webpage; 10) Security, yakni keamanan bertransaksi; dan 11) Sales Promotion, seperti $e$ coupon. Berdasarkan beberapa dimensi di atas, penelitian ini menggunakan dimensi sales promotion, security, dan customer service.

Lebih lanjut, kinerja pemasaran dipengaruhi oleh keunggulan kompetitif. Hal ini sesuai dengan pernyataan Limakrisna \& Yoserizal (2016) bahwa kinerja pemasaran juga tidak terlepas dari keunggulan kompetitif pemasaran yang pasti. Keunggulan kompetitif berpengaruh signifikan terhadap kinerja pemasaran (Nuryakin, 2019).

Selain e-marketing dan keunggulan kompetitif, online review juga dapat memperkuat atau memperlemah kinerja pemasaran. Online review yang ditinggalkan konsumen berupa komentar kontekstual dan gambar kontekstual memperjelas pemahaman konsumen dan mampu meningkatkan minat membeli (Trong \& Tran, 2020). Lebih lanjut, De Pelsmacker et al., (2018) menyatakan bahwa volume dan nilai review berpengaruh terhadap pendapatan perusahaan.

Kinerja pemasaran memiliki banyak dimensi. Namun dalam penelitian ini penulis mengambil dimensi non-financial measures seperti kepuasan pelanggan (customer satisfaction), ekuitas merek (brand equity) dan loyalitas pelanggan (customer loyalty) guna mengukur kinerja pemasaran dari perspektif konsumen. 
Fenomena di tengah era digitalisasi disruptif ini menunjukkan persaingan antar e-commerce sangat gencar dilakukan. Hanya dalam beberapa kuartal, e-commerce pendatang baru mampu menyusul e-commerce yang sudah lebih dulu menjuarai market share di Indonesia. Seperti Shopee yang menyusul Bukalapak dan Tokopedia hanya dalam beberapa kuartal terakhir (Budiansyah, 2020). Oleh sebab itu, perlu diteliti faktorfaktor yang menyebabkan peningkatan kinerja pemasaran dari sudut pandang konsumen.

Mayoritas penelitian terkait e-marketing, online review dan kinerja pemasaran hanya melihat dari perspektif perusahaan, dalam penelitian ini penulis melihat dari perspektif konsumen selaku penentu dalam industri. Sehingga secara holistik akan mengkaji dampak e-marketing dan keunggulan kompetitif terhadap kinerja pemasaran dengan online review sebagai variabel moderating pada perusahaan e-commerce di Indonesia.

\section{METODE PENELITIAN}

Penelitian ini termasuk ke dalam jenis penelitian kuantitatif. Adapun sifat dari penelitian ini dipaparkan secara deskriptif (descriptive explanatory). Penelitian ini menggunakan pendekatan survei melalui kuesioner dengan menggunakan skala likert pada media google form disebabkan oleh masa pandemi Covid-19 namun tetap mematuhi azas valid dalam data. Populasi dalam penelitian ini adalah seluruh pengguna jasa belanja online di e-commerce Indonesia seperti Shopee, Tokopedia, Bukalapak, Zalora, Lazada, Blibli, Bhinneka dan lain sebagainya. Pengambilan sampel dilakukan dengan metode purposive sampling dengan kriteria responden sudah per- nah menggunakan jasa belanja online (e-commerce) minimal 2 kali pembelian pada e-commerce di Indonesia dan sudah berusia 17 tahun ke atas. Teknik pengumpulan data dengan menggunakan data primer (kuesioner) dan data sekunder (studi literatur).

Metode analisis data dalam penelitian ini adalah dengan teknik analisis Partial Least Square-Structural Equation Modeling (PLS-SEM) dengan menggunakan program SMART-PLS. Penelitian ini menggunakan variabel eksogen dan variabel endogen. Variabel eksogen terdiri atas $e$ marketing dan competitive advantage, variabel endogen terdiri atas kinerja pemasaran, dan variabel moderating yaitu online review.

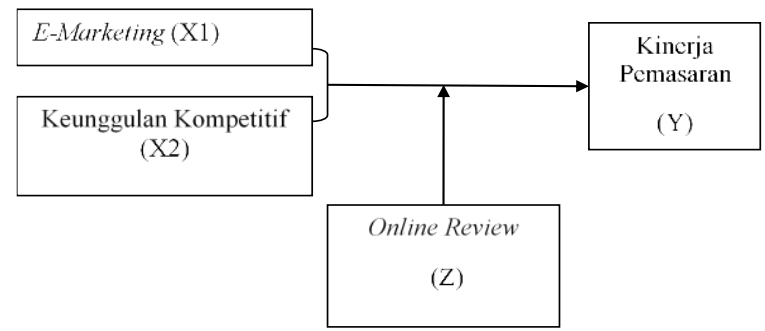

Gambar 1 Kerangka Konseptual

Tujuan penelitian ini adalah untuk mengetahui dan menganalisis tingkat signifikansi faktor $e$-marketing terhadap kinerja pemasaran pada $e$ commerce di Indonesia, untuk mengetahui dan menganalisis tingkat signifikansi faktor keunggulan kompetitif terhadap kinerja pemasaran pada e-commerce di Indonesia, dan untuk mengetahui dan menganalisis tingkat signifikansi pengaruh online review dalam memoderasi hubungan antara e-marketing dan keunggulan kompetitif terhadap kinerja pemasaran pada e-commerce di Indonesia. Kerangka konseptual dilihat pada Gambar 1.

Penelitian ini berfokus pada hubungan antara variabel e-marketing (X1), keunggulan 
kompetitif $(\mathrm{X} 2)$, kinerja pemasaran $(\mathrm{Y})$, dan online review (Z). Hipotesis penelitian ini adalah sebagai berikut:

H1: E-marketing berpengaruh signifikan terhadap kinerja pemasaran pada e-commerce di Indonesia.

H2: Keunggulan kompetitif berpengaruh signifikan terhadap kinerja pemasaran pada $e$ commerce di Indonesia.

H3: Online review mampu memoderasi hubungan antara $e$-marketing dan keunggulan kompetitif terhadap kinerja pemasaran pada e-commerce di Indonesia.

\section{HASIL DAN PEMBAHASAN}

Berdasarkan kuesioner yang disebarkan kepada 51 responden sesuai kriteria, diperoleh profil responden sebagai berikut:

\begin{tabular}{|c|c|}
\hline \multicolumn{2}{|c|}{ Tabel 2. Karakteristik Responden } \\
\hline Karakteristik & Persentase \\
\hline \multicolumn{2}{|l|}{ Jenis Kelamin } \\
\hline Perempuan & $64 \%$ \\
\hline Laki-Laki & $36 \%$ \\
\hline \multicolumn{2}{|l|}{ Usia } \\
\hline$<20$ tahun & $36 \%$ \\
\hline 20-30 tahun & $34 \%$ \\
\hline 31-40 tahun & $24 \%$ \\
\hline 41-50 tahun & $6 \%$ \\
\hline$>50$ tahun & $0 \%$ \\
\hline \multicolumn{2}{|l|}{ Pendapatan } \\
\hline$<$ Rp.1.000.000 & $38 \%$ \\
\hline Rp.1 juta-Rp.2,5 juta & $18 \%$ \\
\hline Rp.2,6 juta-Rp.5 juta & $16 \%$ \\
\hline$>$ Rp.5 juta & $28 \%$ \\
\hline \multicolumn{2}{|l|}{ Pekerjaan } \\
\hline Pelajar & $46 \%$ \\
\hline Karyawan Swasta & $30 \%$ \\
\hline Lainnya & $18 \%$ \\
\hline PNS \& Wiraswasta & $6 \%$ \\
\hline \multicolumn{2}{|l|}{ Jenis E-Commerce } \\
\hline Shopee & $66 \%$ \\
\hline Tokopedia & $16 \%$ \\
\hline Lazada & $14 \%$ \\
\hline Bukalapak \&dll & $4 \%$ \\
\hline
\end{tabular}

Berdasarkan data Tabel 2 diketahui bahwa mayoritas pengguna e-commerce berjenis kelamin perempuan sejumlah 64\%, berusia di bawah 20 tahun sejumlah 36\%, dengan rata-rata pendapatan di bawah Rp.1.000.000 sejumlah 38\%, berstatus pekerjaan sebagai pelajar sejumlah $46 \%$ dan menggunakan e-commerce Shopee sejumlah 66\%. Dengan demikian, dapat diketahui bahwa mayoritas pengguna aplikasi e-commerce adalah pelajar dengan jumlah penghasilan di bawah Rp 1.000.000,00.

Hal ini sesuai dengan sensus penduduk tahun 2020, bahwa dari total 270,2 juta penduduk mayoritas penduduk Indonesia adalah generasi millenial $(25,87 \%)$ dan generasi Z $(27,94 \%)$ yang dibidik oleh e-commerce dengan menggunakan brand ambassador artis Korea (Annur, 2021). Lebih lanjut, Rayful (2021) menyatakan bahwa pelanggan perempuan mendominasi e-commerce di Indonesia sejum-lah $60 \%$ selama masa pandemi. Berdasarkan penelitian (Wahyuddin et al., 2017), perempuan merupakan mayoritas pengguna e-commerce karena perempuan cenderung memiliki orientasi belanja yang bernilai hedonisme.

Pengujian hipotesis dengan model structural equation modelling (SEM) dengan SMART-PLS versi 3.0. Namun sebelumnya, dilakukan evaluasi dari model pengukuran (evaluation of measurement model) terlebih dahulu melalui uji validitas dan reliabilitas. Uji Validitas dilakukan dengan dua metode yaitu melalui uji validitas konvergen (convergent validity) dan uji validitas diskriminan (discriminant validity). Uji validitas konvergen merupakan korelasi antara skor indikator dengan skor konstruknya. Model PLS-SEM memenuhi convergent validity apabila nilai outer loading 
atau loading factor $>0,7$ dan nilai Average Variance Extracted (AVE) > 0,5 (Jogiyanto, 2017).

Berdasarkan hasil evaluasi loading factor, diketahui bahwa terdapat beberapa indikator yang memiliki nilai outer loading atau factor loading di bawah 0,7 yang mengindikasikan bahwa indikator tidak valid untuk menggambarkan konstruk model penelitian. Sehingga data yang tidak valid dikeluarkan dari model. Kemudian dilakukan pengujian ulang terhadap data yang valid. Dengan demikian, indikator X1.1 yaitu promosi penjualan (sales promotion), X2.2 kualitas produk (product quality) dan Y1.3 yaitu loyalitas pelanggan (customer loyalty) dihapus dari model. Lalu dilakukan pengujian kembali yang hasilnya berada di atas 0,7 (sudah valid) yaitu X1.2 (security), X1.3 (Customer Service), X2.1 (uniqueness), X2.3 (price), Y1.1 (customer loyalty), Y1.2 (brand equity), Z1.1 (usefulness), $\mathrm{Z} 1.2$ (needs review of quality), Z1.3 (needs review of price), Z1.4 (needs review of delivery), Z1.5 (needs review of seller response), Z1.6 (needs review of product originality).

Tabel 3 Nilai Evaluasi Average Variance Extracted AVE

\begin{tabular}{l|c}
\hline \multicolumn{1}{c}{ Variabel } & Nilai AVE \\
\hline E-Marketing & 0,739 \\
\hline Keunggulan bersaing & 0,709 \\
\hline Kinerja pemasaran & 0,788 \\
\hline Online Review & 0,790 \\
\hline
\end{tabular}

Sumber : Hasil Penelitian, 2021 (Data diolah)

Selain nilai loading factor, uji validitas konvergen juga dilihat berdasarkan nilai AVE guna menggambarkan nilai setiap variabel. Adapun hasil pengolahan data dari variabel-variabel dalam penelitian ini sudah memiliki nilai AVE > 0,5. Nilai Evaluasi Average Variance Extracted terlihat sebagaimana Tabel 3.
Berdasarkan Tabel 3, diketahui bahwa nilai AVE sudah sesuai dengan kriteria uji validitas konvergen. Selanjutnya dilakukan pengujian validitas diskriminan dengan menggunakan nilai cross loading. Validitas diskriminan terpenuhi apabila nilai cross loading indikator terhadap variabelnya adalah yang terbesar dibandingkan dengan nilai indikator terhadap variabel lainnya.

Proses selanjutnya adalah melakukan pengujian terhadap nilai evaluasi cross loading. Pengujian dilakukan sebanyak dua kali karena terdapat beberapa indikator yang tidak memenuhi kriteria yaitu nilai factor loading di bawah 0,7 .

Terdapat tiga indikator yang tidak valid dengan nilai loading factor $<0,7$ yaitu X1.1 yaitu promosi penjualan (sales promotion), X2.2 kualitas produk (product quality) dan Y1.3 yaitu loyalitas pelanggan (customer loyalty), sehingga data yang tidak valid tersebut dikeluarkan dari model penelitian.

Tabel 4. Nilai Evaluasi Cross Loading

\begin{tabular}{ccccc}
\hline & X1 & X2 & Y & Z \\
\hline X1.2 & 0,911 & 0,322 & 0,667 & 0,395 \\
\hline X1.3 & 0,805 & 0,271 & 0,464 & 0,311 \\
\hline X2.1 & 0,292 & 0,873 & 0,584 & 0,814 \\
\hline X2.3 & 0,293 & 0,809 & 0,485 & 0,565 \\
\hline Y1.1 & 0,465 & 0,609 & 0,870 & 0,613 \\
\hline Y1.2 & 0,713 & 0,533 & 0,905 & 0,506 \\
\hline Z1.1 & 0,415 & 0,776 & 0,555 & 0,893 \\
\hline Z1.2 & 0,39 & 0,766 & 0,578 & 0,912 \\
\hline Z1.3 & 0,362 & 0,715 & 0,521 & 0,880 \\
\hline Z1.4 & 0,238 & 0,711 & 0,466 & 0,885 \\
\hline Z1.5 & 0,373 & 0,712 & 0,596 & 0,853 \\
\hline Z1.6 & 0,412 & 0,741 & 0,593 & 0,909 \\
\hline
\end{tabular}

Sumber : Hasil Penelitian, 2021 (Data diolah)

Berdasarkan Tabel 4 diketahui bahwa semua indikator yang menyusun setiap variabel dalam model penelitian ini telah memenuhi syarat pengujian validitas diskriminan dengan memiliki nilai cross loading di atas nilai 0,7. 


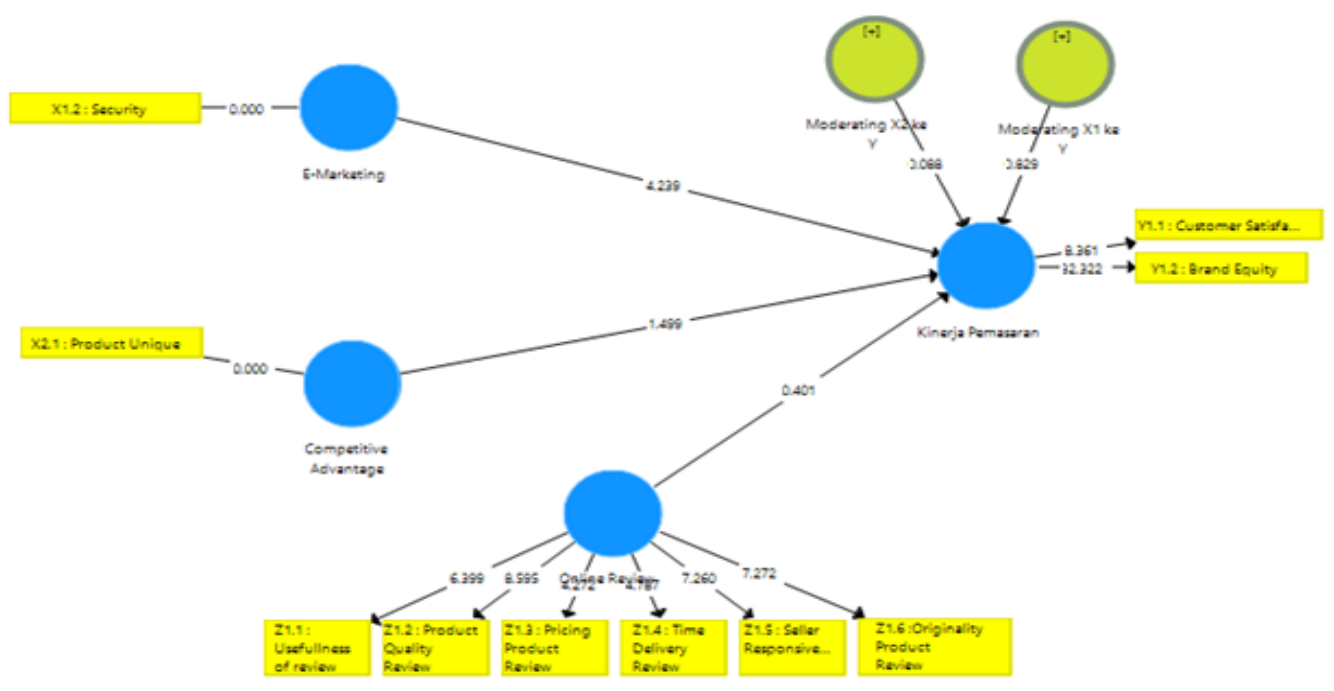

Gambar 2. Model Penelitian setelah Uji Validitas dan Reliabilitas

Setelah melakukan uji validitas, lalu dilakukan uji reliabilitas. Uji reliabilitas penelitian ini dengan menggunakan uji composite reliability dan cronbach's alpha. Composite reliability menguji nilai reliabilitas indikator-indikator pada suatu variabel. Suatu variabel dikatakan memenuhi composite reliability apabila memiliki nilai composite reliability $>0,7$. Nilai composite reliability setiap variabel terlihat sebagaimana Tabel 5.

Tabel 5. Uji Reliabilitas Nilai Composite Reliability Variabel Nilai Composite Reliability

\begin{tabular}{ll}
\hline E-marketing & 0,849 \\
\hline Keunggulan Kompetitif & 0,829 \\
\hline Kinerja Pemasaran & 0,882 \\
\hline Online Review & 0,958 \\
\hline
\end{tabular}

Sumber : Hasil Penelitian, 2021 (Data diolah)

Berdasarkan Tabel 5 di atas diketahui bahwa nilai composite reliability semua variabel lebih besar dari 0,7. Dengan demikian, nilai composite reliability sudah memenuhi persyaratan uji reliabilitas.

Untuk uji reliabilitas pertama, nilai cronbach's alpha e-marketing dan keunggulan kompetitif di bawah 0.7 sehingga harus dilakukan evaluasi ulang dengan menghilangkan indikator yang memiliki nilai terkecil. Terdapat dua indikator yang dikeluarkan dari model penelitian yaitu customer service (X1.3), price competetiveness (X2.3). Pengujian reliabilitas dengan nilai cronbach's alpha dilakukan sebanyak dua kali sehingga didapatkan hasil yang sesuai kriteria.

\begin{tabular}{|c|c|}
\hline Variabel & $\begin{array}{ll}\text { R-Square } & \text { R-Square Adjsuted }\end{array}$ \\
\hline Kinerja Pemasaran & 0,613 \\
\hline \multicolumn{2}{|c|}{ Sumber : Hasil Penelitian, 2021 (Data diolah) } \\
\hline \multicolumn{2}{|c|}{ Berdasarkan hasil olah data, diperoleh nilai } \\
\hline \multirow{6}{*}{\multicolumn{2}{|c|}{$\begin{array}{l}\text { R-Square pada tabel } 6 \text {. Tabel } 6 \text { menunjukkan } \\
\text { bahwa variabel kinerja pemasaran dipengaruhi } \\
\text { oleh variabel e-marketing, keunggulan kompetitif } \\
\text { dan online review sebesar } 0,644 \text { atau } 64,4 \% \text { se- } \\
\text { mentara sisanya dipengaruhi oleh variabel-varia- } \\
\text { bel lain di luar penelitian ini. }\end{array}$}} \\
\hline & \\
\hline & \\
\hline & \\
\hline & \\
\hline & \\
\hline \multirow{4}{*}{\multicolumn{2}{|c|}{$\begin{array}{l}\text { Nilai path coefficient menunjukkan sebe- } \\
\text { rapa besar pengaruh variabel eksogen terhadap } \\
\text { variabel endogen. Berdasarkan hasil pengolahan } \\
\text { data, diperoleh nilai path coefficient sebagaimana }\end{array}$}} \\
\hline & \\
\hline & \\
\hline & \\
\hline \multicolumn{2}{|l|}{ Tabel 7.} \\
\hline \multicolumn{2}{|c|}{ Tabel 7. Nilai Path Coefficient } \\
\hline Variabel & Kinerja Pemasaran \\
\hline -marketing & \\
\hline eunggulan Kompetitif & 0,234 \\
\hline Online Review & 0,082 \\
\hline
\end{tabular}


Sumber : Hasil Penelitian, 2021 (Data diolah)

Berdasarkan Tabel 7 diketahui bahwa: variabel e-marketing memiliki pengaruh positif terhadap kinerja pemasaran senilai 0,472 , variabel keunggulan kompetitif memiliki pengaruh positif terhadap kinerja pemasaran senilai 0,234 , variabel online review memiliki pengaruh positif terhadap kinerja pemasaran senilai 0,082.

Uji $t$-statistic pada SMART-PLS 3.0 dilakukan dengan membandingkan nilai t-statistic dengan nilai $t$-tabel. Hubungan antara variabel dikatakan signifikan jika t-statistik $>1,96$ atau nilai $p$-values $<0,05$ atau berwarna hijau pada program SMART PLS.

Tabel 8. Nilai Uji T-Statistik Kinerja Pemasaran

\begin{tabular}{lcc}
\hline \multirow{2}{*}{ Variabel } & \multicolumn{2}{c}{ Kinerja Pemasaran } \\
\cline { 2 - 3 } & t-statistic & P-Values \\
\hline E-Marketing & 4,335 & 0,000 \\
\hline Keunggulan Kompetitif & 1,448 & 0,148 \\
\hline Online Review & 0,432 & 0,666 \\
\hline
\end{tabular}

Sumber : Hasil Penelitian, 2021 (Data Diolah)

Berdasarkan Tabel 8 diketahui hasil uji parsial sebagai berikut:

1. Nilai t-statistik untuk variabel e-marketing $(4,335)$ lebih besar dibanding nilai t-tabel 1,96 dan nilai $p$-values sebesar 0,00 jauh di bawah 0,05 . Dengan demikian dapat disimpulkan bahwa $\mathrm{H} 1$ diterima untuk e-marketing dan Ho ditolak. Sehingga dapat disimpulkan bahwa $E$ marketing berpengaruh signifikan terhadap kinerja pemasaran. Adanya pengaruh yang signifikan antara e-marketing terhadap kinerja pemasaran memberikan gambaran positif bahwa e-marketing yang dilakukan oleh perusahaan e-commerce sudah cukup baik sehingga kinerja pemasaran meningkat. Hal ini sejalan dengan hasil penelitian Priyanto et al., (2020) bahwa terdapat pengaruh positif dan siginifikan dalam implementasi e-marketing terhadap kinerja pemasaran UKM kluster kuliner Kota Bogor. Begitu pula dengan hasil penelitian Kuswanto et al., (2021) pada toko sayuran online di Surabaya, bahwa pemasaran digital berpengaruh terhadap kinerja pemasaran.

2. Nilai t-statistik untuk variabel keunggulan kompetitif $(1,448)$ lebih rendah dibanding ttabel 1,96 dan nilai $p$-values sebesar 0,148 jauh di atas 0,05. Sehingga dapat disimpulkan bahwa $\mathrm{H} 1$ ditolak untuk keunggulan kompetitif dan Ho diterima. Artinya secara parsial keunggulan kompetitif tidak berpengaruh secara signifikan terhadap kinerja pemasaran. Nilai ini mengindikasikan bahwa keunggulan kompetitif antara perusahaan e-commerce terhadap kinerja pemasaran masih rendah. Sehingga diperlukan upaya lebih guna meningkatkan keunggulan kompetitif antar $e$ commerce. Hal ini sejalan dengan hasil penelitian Asyhari et al., (2018) bahwa keunggulan kompetitif mampu menurunkan pengaruh variabel kualitas strategi bisnis terhadap kinerja bisnis sehingga menjadi tidak signifikan. Sebaliknya, penelitian Dewi \& Ekawati (2017) menunjukkan bahwa keunggulan kom-petitif berpengaruh terhadap kinerja pemasaran.

3. Nilai t-statistik untuk variabel online review $(0,432)$ jauh lebih rendah di bawah $t_{\text {-tabel }} 1,96$ dan nilai $p$-values sebesar 0,666 lebih besar dari nilai t-sig 0,05. Dengan demikian dapat disimpulkan bahwa $\mathrm{H} 1$ ditolak untuk online review dan Ho diterima. Artinya secara parsial online review tidak berpengaruh signifikan terhadap kinerja pemasaran. Hal ini menunjuk- 
kan bahwa masih rendahnya fungsi variabel online review dalam meningkatkan kinerja $e$ commerce. Para konsumen belum mema-hami pentingnya meninggalkan online review dan menjadikan online review sebagai bahan referensi sebelum melakukan pembelian suatu produk di e-commerce. Berbeda dengan hasil penelitian Cui et al., (2016) yang menunjukkan bahwa jumlah online review berpengaruh terhadap peningkatan penjualan produk baru pada masa awal penjualan dan menurun setelahnya. Namun, review negative berdampak besar terhadap penurunan penjualan produk. Lebih lanjut, berdasarkan konfirmasi hasil penelitian di lapangan kepada para responden, diketahui bahwa online review hanya mempengaruhi kinerja pemasaran dari seller atau merchant pada e-commerce. Sehingga tidak terlalu berdampak pada kinerja pemasaran e-commerce secara keseluruhan.

Nilai predictive relevance adalah nilai yang menunjukkan seberapa baik nilai observasi yang dihasilkan. Nilai predictive relevance dilakukan dengan menggunakan metode blindfolding pada aplikasi SMART-PLS. Adapun nilai predictive relevance terlihat pada tabel 9.

Tabel 9. Nilai Predictive Relevance

\begin{tabular}{cc}
\hline Predictive Relevance & $\mathbf{Q}^{\mathbf{2}}(\mathbf{= 1 - S S E} / \mathbf{S S O})$ \\
\hline Kinerja Pemasaran & 0,385 \\
\hline Sumber : Hasil Penelitian, 2021 (Data Diolah)
\end{tabular}

Berdasarkan Tabel 9 diketahui bahwa nilai predictive relevance berada di antara 0 dan 1 yaitu 0,385. Hal ini mengindikasikan bahwa nilai observasi yang dihasilkan dalam penelitian ini sudah cukup bagus dan menggambarkan model penelitian. Namun apabila nilai observasi di bawah 0 , hal ini mengindikasikan nilai observasi yang tidak bagus.

Model of fit adalah nilai yang menunjukkan seberapa baik model yang dimiliki. Model of fit dilihat melalui nilai NFI. Semakin tinggi nilai NFI maka semakin baik model penelitian. Berdasarkan hasil pengolahan data, diperoleh hasil nilai NFI sebagai berikut:

Tabel 10. Model of Fit

\begin{tabular}{ccc}
\hline Model Fit & Saturated Model & $\begin{array}{c}\text { Estimated } \\
\text { Model }\end{array}$ \\
\hline NFI & 0,831 & 0,854 \\
\hline
\end{tabular}

Sumber : Hasil Penelitian, 2021 (Diolah)

Berdasarkan Tabel 10 di atas diketahui bahwa nilai NFI pada estimated model adalah sebesar 0,854 yang artinya bahwa model dalam penelitian ini sudah $85.4 \%$ fit. Berdasarkan hasil uji hipotesis diperoleh hasil seperti pada Tabel 11.

Tabel 11. Hasil Hipotesis

\begin{tabular}{|c|c|c|c|}
\hline Hipotesis & SEM & $\begin{array}{c}\begin{array}{c}p- \\
\text { values } \\
<0.05\end{array} \\
\end{array}$ & Nilai \\
\hline $\begin{array}{l}\text { H1 : E-marketing } \\
\text { berpengaruh positif dan } \\
\text { signifikan terhadap } \\
\text { kinerja pemasaran pada } \\
\text { e-commerce di Indonesia. }\end{array}$ & 0,472 & 0,000 & Diterima \\
\hline $\begin{array}{l}\text { H2 : Keunggulan } \\
\text { kompetitif berpengaruh } \\
\text { positif dan signifikan } \\
\text { terhadap kinerja } \\
\text { pemasaran pada } e \text { - } \\
\text { commerce di Indonesia. }\end{array}$ & 0,234 & 0,148 & Ditolak \\
\hline $\begin{array}{l}\text { H3 : Online review dapat } \\
\text { memoderasi hubungan } \\
\text { antara } \text {-marketing dan } \\
\text { keunggulan kompetitif } \\
\text { terhadap kinerja } \\
\text { pemasaran pada } e \text { - } \\
\text { commerce di Indonesia. }\end{array}$ & 0,082 & 0,666 & Ditolak \\
\hline
\end{tabular}

Sumber : Hasil Penelitian, 2021 (Data diolah)

\section{SIMPULAN}

Berdasarkan hasil penelitian dan pembahasan yang telah diuraikan di atas, maka dapat dirumuskan kesimpulan sebagai berikut: 
1. E-Marketing memiliki dampak positif dan signifikan terhadap kinerja pemasaran pada $e$ commerce di Indonesia.

2. Keunggulan kompetitif memiliki dampak positif namun tidak signifikan terhadap kinerja pemasaran pada e-commerce di Indonesia.

3. Online review memiliki dampak positif namun tidak signifikan dalam memoderasi hubungan antara e-marketing dan keunggulan kompetitif terhadap kinerja pemasaran pada $e$ commerce di Indonesia.

\section{DAFTAR PUSTAKA}

Annur, C. M. (2021). Pengaruh Artis K-Pop dan Influencer Menggaet Pasar E-Commerce.pdf. https://katadata.co.id/ariayudhistira/analisisdat a/60abaa6d421e6/pengaruh-artis-k-pop-daninfluencer-menggaet-pasar-e-commerce

Asyhari, Pudjihastuti, S. H., \& Kurdaningsih, D. M. (2018). Peran mediasi keunggulan kompetitif pada faktor determinan kinerja bisnis UKM di sentra tenun batik di Jawa Tengah. 22(2), 111131.https://doi.org/10.20885/jsb.vol22.iss2.art1

Badan Pusat Statistik. (2019). Statistik E-Commerce 2019. In Badan Pusat Statistik. https://www.bps.go.id/publication/2019/12/18 /fd1e96b05342e479a83917c6/statistik-ecommerce-2019.html

Budiansyah, A. (2020). Shopee Nomor Satu, Tokopedia Kedua, Bukalapak Apa Kabar? Https://Www.Cnbcindonesia.Com/Tech/202003 12142052-37-144382/Shopee-Nomor-SatuTokopedia-Kedua-Bukalapak-Apa-Kabar. https://www.cnbcindonesia.com/tech/2020031 2142052-37-144382/shopee-nomor-satutokopedia-kedua-bukalapak-apa-kabar

Cui, G., Lui, H., \& Guo, X. (2016). The Effect of Online Consumer Reviews on New Product Sales The Effect of Online Consumer Reviews on New Product Sales. October 2012. https://doi.org/10.2307/41739503

De Pelsmacker, P., van Tilburg, S., \& Holthof, C. (2018). Digital marketing strategies, online reviews and hotel performance. International Journal of Hospitality Management, 72(July 2017), 47-55. https://doi.org/10.1016/j.ijhm.2018.01.003

Dewi, N. M. P., \& Ekawati, N. W. (2017). Fakultas Ekonomi dan Bisnis Universitas Udayana, Bali, Indonesia PENDAHULUAN Usaha Kecil Menengah ( UKM ) adalah sebuah bisnis yang memiliki sifat mandiri dan memiliki peranan penting dalam pertumbuhan ekonomi di suatu negara.
Kontribusi UKM adalah pen. 6(9), 4947-4977.

Iddris, F., \& Ibrahim, M. (2015). Examining the relationships between e-Marketing adoption And Marketing Performance of Small and Medium Enterprises in. Journal of Marketing and Consumer Research, 10(2015), 160-170.

Irmal, Gustiarani, E., \& Sunarsi, D. (2020). Pengaruh EMarketing dan E-CRM Terhadap E-Loyalty Pengunjung Situs Website www.cangkirbogor.com. 2(2), 326-332. http://openjournal.unpam.ac.id/index.php/JEE/a rticle/view/4175/3167

Jogiyanto, H. M. (2017). Analisis dan Desain (Sistem Informasi Pendekatan Terstruktur Teori.docx.pdf. Penerbit Andi. https://scholar.google.com/citations?view_op=vi ew_citation\&hl=en\&user=6eDyhRgAAAAJ\&citatio n_for_view=6eDyhRgAAAAJ:u5HHmVD_u08C

Kuswanto, D. H., Nugroho, S. D., \& Yuliati, N. (2021). FAKTOR-FAKTOR YANG MEMPENGARUHI KINERJA PEMASARAN PADA TOKO SAYURAN ONLINE DI KOTA SURABAYA FACTORS. Jurnal Ilmiah Mahasiswa, 8, 420-433.

Limakrisna, N., \& Yoserizal, S. (2016). Determinants of marketing performance: empirical study at National Commercial Bank in Jakarta Indonesia. SpringerPlus, $5(1)$. https://doi.org/10.1186/s40064-016-3362-3

Magdalena, H., \& Ellyani, W. (2018). Strategi memanfaatkan e-commerce dalam memasarkan makanan khas Bangka (Studi Kasus : Aneka Citra Snack). CogITo Smart Journal, 3(2), 286. https://doi.org/10.31154/cogito.v3i2.64.286298

Mariana, M. (2012). Apa itu e-commerce.pdf. http://www.unpas.ac.id/apa-itu-e-commerce/

Nayoan, A. (2021). Apa itu E-commerce? Berikut Pengertian, Jenis, serta Manfaatnya! https://www.niagahoster.co.id/blog/apa-ituecommerce/

Nuryakin. (2019). COMPETITIVE ADVANTAGE AND PRODUCT INNOVATION KEY SUCCESS OF BATIK SMES MARKETING. Academy of Strategic Management Journal. http://repository.umy.ac.id/bitstream/handle/1 23456789/30435/C.12-COMPETITIVE ADVANTAGE AND PRODUCT INNOVATION KEY SUCCESS OF BATIK SMES MARKETING PERFORMANCE IN INDONESIA $\% 281 \% 29$.pdf? sequence $=4$ \&isAllowed $=y$

Priyanto, H., Najib, M., \& Septiani, S. (2020). Faktor Adopsi E-Marketing dan Pengaruhnya Terhadap Kinerja Pemasaran UKM Kuliner Kota Bogor. 10(January 2021), 235-244. https://doi.org/10.21456/vol10iss2pp235-244

Rayful, M. (2021). Selama pandemi, 60 persen pelanggan e-commerce dari kalangan perempuan. In Bisnis.com. https://lifestyle.bisnis.com/read/20210309/220 
Salqaura, S.A., Sipayung, R.C. \& Salqaura, S.S. (2021). E-Marketing dan Keunggulan Kompetitif Terhadap Kinerja ...

/1365908/selama-pandemi-60-persenpelanggan-e-commerce-dari-kalanganperempuan.

Tjiptono, F., \& Chandra, G. (2020). Pemasaran Strategik Domain, Determinan, Dinamika.pdf. Penerbit Andi.

Trong, L., \& Tran, T. (2020). Online reviews and purchase intention: A cosmopolitanism perspective. Tourism Management Perspectives, 35(October 2019), 100722. https://doi.org/10.1016/j.tmp.2020.100722

Wahyuddin, M., Setyawan, A. A., \& Nugroho, S. P.
(2017). Shopping Behavior Among Urban Women. Mediterranean Journal of Social Sciences, $8(1)$, 306-311. https://doi.org/10.5901/mjss.2017.v8n1p306

Zhao, X. (Roy), Wang, L., Guo, X., \& Law, R. (2015). The influence of online reviews to online hotel booking intentions. International Journal of Contemporary Hospitality Management, 27(6), 1343-1364. https://doi.org/10.1108/IJCHM-122013-0542 